\title{
ECONOMIC ASPECTS OF PHYTOREMEDIATION
}

\author{
T. Thewys \\ Hasselt University, Belgium
}

\begin{abstract}
The replacement of a traditional crop in favor of a phytoremediating culture is not a neutral operation. The social acceptability of introducing a phytoremediating crop depends on the condition that the net present value of the gross labor income (the total revenue diminished by the non-labor variable costs) earned on the area to be cleaned up and calculated over a sufficient long period, is at least not decreased. The case study considered applies to a large area cross bordering the eastern part of Flanders and the Netherlands characterized with diffuse heavy metal pollution. The reclamation activity aims at removing $2,5 \mathrm{~kg}$ to $5,4 \mathrm{~kg}$ cadmium/ha. As a social acceptable, but weak phytoremediation scenario, the yearly cultivation scheme for a 'modal' farmer starts with 14 ha of rape (in 4 year rotation); 4 ha of willow (with harvest every $4^{\text {th }}$ year) and 18 ha of roughage. The resulting median net present value (NPV) over a period of 40 years of the gross labor income is nearly the same as the NPV of continuing the current land occupation (the benchmark), that is 36 ha only for roughage. However, taking into account the uncertainty of the assumed values for important parameters, the probability of obtaining a lower value for the NPV than currently is, is $62 \%$. We also note that after 40 years only $22 \%$ of the surface is satisfying the remediation target. Increasing the ratio of willow versus rape to $14 \mathrm{ha} / 4$ ha results in the sanitation of the total 36 ha after 32 years (willow has a higher uptake performance than rape). On top of this, the median value for the NPV is now $5 \%$ larger than the benchmark due to the expected larger labor income on the 'cleaned' hectares. In this scenario the probability of obtaining a lower value for the NPV than currently is only $15 \%$.
\end{abstract}

\section{KEYWORDS}

Phytoremediation, agricultural economics, cost-benefit analysis, net present value, decision making

\section{INTRODUCTION}

\subsection{Phytoremediation: lowest costs}

Phytoremediation is often presented as a low capital intensive and so low cost remediation technique especially relevant for diffuse (moderate) pollution in large areas [1, 2]. Its economical attractiveness is demonstrated by comparing the phytoremediation costs with those of the more traditional techniques like excavating, soil washing etc. [3]. Such comparisons are only meaningful if there is a common remediation target what means that the remediation periods can vastly differ. From this perspective phytoremediation, because of the longer time period it needs, has a main disadvantage. If a traditional reclamation technique reaches the target much faster than phytoremediation, an economist would think of the earlier 
regained revenues on the cleaned site as diminishing the higher costs of that traditional technique when comparing with the costs of phytoremediation.

\subsection{A cost-benefit approach}

In deciding which reclamation technique to adopt one should consider cost and benefit elements over the whole remediation period. Particular attention should go to the most important cost drivers and benefit elements that strike the balance in favor of phytoremediation. Such decision making can be assisted by the device called 'cost-benefit analysis' in which - at least as far as it is measurable - the timely evolution of costs and benefits of phytoremediation can be considered. Assuming a predefined time period for the study (which can be changed as an element of sensitivity analysis), the cost-benefit approach could distinguish the following items:

1 The cost of the phytoremediation action: capital and operational costs will be strongly connected with the pollutant removal performance of the remediation crop, the soil conditions, the difference between the initial and the target level of pollution, etc. All these items will also determine the length of the remediation period.

2 The lost income that the soil is still generating even in its polluted situation.

3 The eventual income through the valorization of the harvested biomass. This can be considered as 'recovering' some of the costs of phytoremediation ' [4].

4 The income increase associated with the soil after it is considered 'clean', determined by its functional use for which the reclamation target is decisive.

These items have to be considered over a predefined study period, covering the remediation period plus the period of prospected regained income from the 'cleaned' soil. From the point of view of the owner of the soil such a period could be, e.g. 30-40 years. Discounting the costs and benefits over the study period, one arrives at the "net present value" (NPV) of the phytoremediation alternative ${ }^{2}$ [5]. This NPV can be used to analyze its 'sensitivity' for changes in important parameters like the relative number of ha of crops with different metal accumulating performances, the revenue from the biomass, the level of regained income versus actual income of the soil etc. Phytoremediation seems particular applicable in the context of 'land management' of large areas where the remediation target can be adapted to (i) the ultimate future land use, and (ii) the intermediate land use in cases where the area is actually a source of agricultural income. In the latter circumstances the gradual adoption of phytoremediation crops (accumulators) will depend amongst others on the repercussions on the income of the local farmers. In this context one can use 'labor income per hectare per year' as a measurement concept. It means the gross revenue of any (labor) activity on the soil (before and after reclamation) after deduction of capital and operational costs. The costbenefit approach could be represented as in Figure 1 [6]

\footnotetext{
${ }^{1}$ We remark that the ITRC, in developing a 'Decision tree for Phytoremediation for polluted soils", formulates the question: "Can the plant waste be economically disposed?" Only the "Yes" answer leads to the advice that "Phytoremediation has the potential to be effective at the site" (ITRC, 1999, p. 14)

2 In one of the rare investigations on the economic viability of phytoextraction, Robinson et.al. (2003) followed an approach which goes a long away according to cost-benefit analysis.
} 


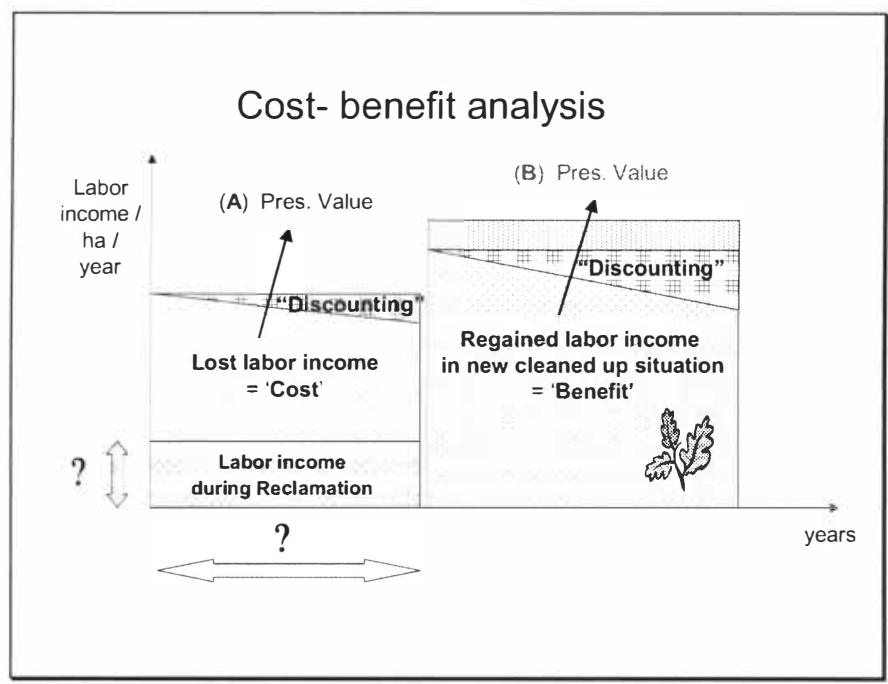

Figure 1 Phytoremediation: the cost-benefit approach [6]

In this figure the labor income after sanitation is assumed to be larger than before the phytoremediation. It is also assumed that during the remediation period there is a possibility for a positive labor income stemming e.g. from processing the biomass. This income should be considered as net of all costs - of phytoremediation itself (the 'system costs') and of all processing costs involved in valorization of the biomass. Of course, if the revenue from valorization is too small (or absent) to compensate for the costs ofephytoremediation, the labor income during remediation is negative. The 'Lost labor income' during the remediation period is to be considered as the difference between the (abandoned) revenue from the polluted soil diminished with the possible 'Labor income during reclamation'. From the point of view of the user of the soil, this forms the "(opportunity) cost" of the reclamation. The NPV is calculated as the difference between the present value of the "Regained labor income in the new cleaned up situation' (B) and the present value of 'Lost labor income' (A).

\subsection{Phytoremediation: Cost Recovery}

To date, commercial phytoextraction has been constrained by the expectation that site remediation should be achieved in a time comparable to other clean-up technologies. However, if phytoextraction could be combined with a revenue-earning operation, then this time constraint, which has often been considered to be the Achilles heel of phytoextraction, may become less important. Cost recovery (meaning labor income during the reclamation period) and the appropriateness of including it as a plant selection criterion, is the subject of increasing current research. Given the local settings of the study area, we consider the following phytoremediation crops and according valorization possibilities. 


\subsubsection{Oil seed rape}

This crop is not unfamiliar to the local farmers: a few decades ago it was substituted by maize and grassland which were more suitable in intensive dairy cattle rearing. Recently, because of the upsurge in energy prices, oil seed rape again became interesting as a crop fit for "energyfarming'. In an endeavour to keep the value added activity in the region itself, we opt for the physical conversion of pressing and extracting oil from the biomass, done by a cooperation of local farmers. The oil can partly be used by the farmers themselves but mostly be sold to the local market, substituting fossil fuel in adapted engines or heating installations. We assume a selling price less than the diesel price, in the neighborhood of $€ 0.75$ per liter. In our simulations this price varies over a range between $€ 0.5$ and $€ 1$ per liter. This price develops proportional to the fossil oil price. The yearly growth rate of the latter is assumed to be $2 \%$ with a range of $1 \%$ to $4 \%$ (see below). Oil seed rape is grown with an intermittence of 3 years. It's uptake of cadmium is rather moderate.

\subsubsection{Willow as short rotation coppice}

Willow as short rotation coppice (SRC) has - in comparison with rape - a double as large uptake performance (see Table 1). It is a crop definitely shortening the length of the remediation period. Unfortunately growing woody crops is not popular in the agricultural sector, a.o. because of the uprooting costs if the farmer wants to switch again to a traditional culture. Also the Belgian legislation treats woody crops very differently from agricultural crops, e.g. the obligation to hold the crop for certain duration to receive subsidies. Moreover, the outlets for the SRC in the region were such that the revenue from SRC was not covering the growing costs, so that the yearly labor income per hectare was negative $(€-98)$. The harvest of the SRC is assumed to happen every 4 years.

Table 1: Cadmium transport (or uptake) data

\begin{tabular}{|c|c|c|c|}
\hline & Transport & Rape & Willow \\
\hline$(1)$ & Necessary transport to reach target $(\mathrm{kg} / \mathrm{ha})$ & 2.52 & 5.4 \\
\hline$(2)$ & Rape: yearly transport Cd $(\mathrm{kg} / \mathrm{ha})$ & 0.07 & \\
\hline$(3)$ & Willow stems only: yearly transport Cd $(\mathrm{kg} / \mathrm{ha})$ & & 0.144 \\
\hline
\end{tabular}

Source: communication from biologists of the Center for Environmental Studies, UHasselt.

\section{AGRICULTURAL LABOR INCOME}

\subsection{Actual soil pollution and target}

The case study considered applies to a large area cross bordering the eastern part of Flanders and the Netherlands where diffuse heavy metal pollution is a heritage from the historical zinc smelters in the region. The reclamation activity aims at removing $2.5 \mathrm{~kg}$ to $5.4 \mathrm{~kg} \mathrm{Cd} / \mathrm{ha}$. 
Table 2: Soil pollution and remediation target

\begin{tabular}{|c|l|c|c|}
\hline & & Rape & Willow \\
\hline & Target Cd level & & \\
\hline$(1)$ & Concentration Cd (mg/kg d.m.) & 0.5 & 0.5 \\
\hline$(2)$ & Allowed pollution of soil $(\mathrm{kg} / \mathrm{ha})$ & 1.8 & 1.8 \\
\hline$(3)$ & Area (ha) & $\mathbf{1}$ & $\mathbf{1}$ \\
\hline$(4)$ & Depth of soil $(\mathrm{m})$ & 0.3 & 0.5 \\
\hline & & & \\
\hline & Actual pollution & & \\
\hline$(5)$ & Concentration Cd $(\mathrm{mg} / \mathrm{kg} \mathrm{d.m.)}$ & 4.3 & 1.2 \\
\hline$(6)$ & Pollution of soil $(\mathrm{kg} / \mathrm{ha})$ & & \\
\hline & Removal & 2.5 & 5.4 \\
\hline$(7)=(6)-(2)$ & Necessary removal to reach target $(\mathrm{kg} / \mathrm{ha})$ & \\
\hline
\end{tabular}

Source: communication from biologists of the Center for Environmental Studies, UHasselt.

\subsection{Cultivation crops and rotation}

The lion's share of the labor income of the local farmers consists of dairy cattle rearing. That is why for the vast majority the agricultural crops are indicated as 'roughage' subdivided in maize and grass. The agricultural survey for the year 2004 showed that the labor income for the current activity, was $€ 1.100$ per ha [7]. On the Belgian side of the border, there are 230 farmers confronted with soil pollution. In our analysis we will consider the situation of a 'modal' farmer cultivating on average 36 ha.

We will assume that on half of this surface ( $18 \mathrm{ha}$ ) phytoremediation (using willow and rape) will be started, the other 18 ha (or more) will stay occupied by roughage as feedstock for the cattle (see

Figure 2, column 1). Because of the necessity of rotation, in many years the total area for phytoremediation is smaller than 18 hectares, see

Figure 2, columns 2-20). Two phytoremediation crops are considered: (i) rape (Brassica nappus), and (ii) willow (Salix spp.) as 'short rotation coppice'. 
Kalmar ECO-TECH '07

KALMAR, SWEDEN, November 26-28, 2007

\begin{tabular}{|c|c|c|c|c|c|c|c|c|c|c|c|c|c|c|c|c|c|c|c|c|}
\hline & \multicolumn{10}{|c|}{ Year } \\
\hline Ha & 1 & 2 & 3 & 4 & 5 & 6 & 7 & 8 & 9 & 10 & 11 & 12 & 13 & 14 & 15 & 16 & 17 & 18 & 19 & 20 \\
\hline 1 & & & & & & & & & & & & & & & & & & & & \\
\hline 2 & & & & & & & & & & & & & & & & & & & & \\
\hline 3 & & & & & & & & & & & & & & & & & & & & \\
\hline 4 & & & & & & & & & & & & & & & & & & & & \\
\hline 5 & & & & & & & & & & & & & & & & & & & & \\
\hline 6 & & & & & & & & & & & & & & & & & & & & \\
\hline 7 & & & & & & & & & & & & & & & & & & & & \\
\hline 8 & & & & & & & & & & & & & & & & & & & & \\
\hline 9 & & & & & & & & & & & & & & & & & & & & \\
\hline 10 & & & & & & & & & & & & & & & & & & & & \\
\hline 11 & & & & & & & & & & & & & & & & & & & & \\
\hline 12 & & & & & & & & & & & & & & & & & & & & \\
\hline 13 & & & & & & & & & & & & & & & & & & & & \\
\hline 14 & & & & & & & & & & & & & & & & & & & \\
\hline 15 & & & & & & & & & & & & & & & & & & & & \\
\hline 16 & & & & & & & & & & & & & & & & & & & & \\
\hline 17 & & & & & & & & & & & & & & & & & & & & \\
\hline 18 & & & & & & & & & & & & & & & & & & & & \\
\hline 19 & & & & & & & & & & & & & & & & & & & \\
\hline 20 & & & & & & & & & & & & & & & & & & \\
\hline 21 & & & & & & & & & & & & & & & & & & \\
\hline 22 & & & & & & & & & & & & & & & & & & & \\
\hline 23 & & & & & & & & & & & & & & & & & \\
\hline 24 & & & & & & & & & & & & & & & & & & & \\
\hline 25 & & & & & & & & & & & & & & & & & & & \\
\hline 26 & & & & & & & & & & & & & & & & & & & \\
\hline 27 & & & & & & & & & & & & & & & & & & & \\
\hline 28 & & & & & & & & & & & & & & & & & & & \\
\hline 29 & & & & & & & & & & & & & & & & & & & \\
\hline 30 & & & & & & & & & & & & & & & & & & & \\
\hline 31 & & & & & & & & & & & & & & & & & & & \\
\hline 32 & & & & & & & & & & & & & & & & & & & & \\
\hline 33 & & & & & & & & & & & & & & & & & & & & \\
\hline 34 & & & & & & & & & & & & & & & & & & & \\
\hline 35 & & & & & & & & & & & & & & & & & & & \\
\hline 36 & & & & & & & & & & & & & & & & & & & \\
\hline
\end{tabular}

Figure 2: Rotation scheme scenario 2: SRC: 9 ha; Rape: 9 ha; Roughage: 18 ha (first 20 years of 40 )

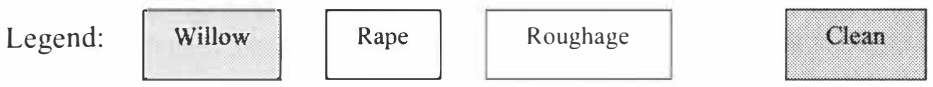

A second important assumption is that the livestock will not be diminished, so that the revenue from selling milk stays the same. This implies that - to arrive at the previous amount of roughage (from 36 ha before) - an amount corresponding to the hectares now occupied 
with willow and rape, has to be bought from farmers outside the region. Another observation is that the total amount of subsidies for home grown maize is lower than before.

\subsection{Labor income during and after phytoremediation}

If no phytoremediation would take place, the current activity, dairy cattle rearing for which the land occupation is roughage (grassland and maize), results in a yearly labor income of $€$ 1.100 per ha for the 'modal' farmer. The corresponding net present value over 40 years (discount rate $5 \%$ ) amounts to $€ 679.500$. We will consider this as the reference or 'benchmark' amount with which the NPV results of the scenarios below are compared.

Phytoremediation, as embedded in a 'land management' option for the case study considers two crops: oil seed rape (low metal uptake performance but offering higher income possibilities), and willow as 'short rotation coppice' (higher metal transport performance but having a negative financial return). With the intention to create value added as much as possible on the farm itself, we opt for the production of pure plant oil (PPO) by a cooperation of farmers. The oil is sold as a transport fuel or as an input for biodiesel production. For every outlet a specific price is used. During the phytoremediation period (i. e. the time to reach the target concentration of $0,5 \mathrm{mg} \mathrm{Cd}$ per $\mathrm{kg}$ dry matter), we can calculate the yearly labor income per ha as follows (see Table 3 for the specific data used in the calculation).

Labor income per hectare per year during phytoremediation

$=$ total area $*$ labor income from roughage $/$ ha

Less (area rape + area willow) * (cost external roughage - cost own roughage)/ha (area maize before + area maize while remediation) ${ }^{*}$ subsidy maize / ha

Plus area rape * labor income from rape / ha

area willow * labor income from willow as SRC / ha

Table 3: Data on labor income per ha during phytoremediation

\begin{tabular}{|c|c|c|}
\hline & & Amount \\
\hline$(1)$ & Actual labor income from roughage before phytoremediation $(€ / \mathrm{ha})$ & 1,100 \\
\hline$(2 \mathrm{a})$ & Cost external roughage $(€ / \mathrm{ha})$ & 1,100 \\
\hline$(2 \mathrm{~b})$ & Cost own produced roughage $(€ / \mathrm{ha})$ & 880 \\
\hline$(3)$ & Subsidy maize $(€ / \mathrm{ha})$ & 300 \\
\hline & Rape oil output $($ lit/ha) & 1,485 \\
\hline$(4 \mathrm{a})$ & Selling price rape oil $(€ / \mathrm{lit})$ & 0.75 \\
\hline$(4 \mathrm{~b})$ & Rape cake $(\mathrm{kg} / \mathrm{ha})$ & 3,015 \\
\hline$(5 \mathrm{a})$ & Rape cake price $(€ / \mathrm{kg})$ & 0.145 \\
\hline$(5 \mathrm{~b})$ & Subsidy Energy crop non fallow land & 365 \\
\hline$(6)$ & Labor income rape $(€ /$ ha $)=(4 \mathrm{a}) *(4 \mathrm{~b})+(5 \mathrm{a}) *(5 \mathrm{~b})+(6)$ & 1,916 \\
\hline$(7)$ & Labor income willow as $\mathrm{SRC}(€ / \mathrm{ha})$ & -98 \\
\hline & & \\
\hline$(8)$ & & \\
\hline
\end{tabular}


Once the heavy metal concentration is lowered so that the target of $1.8 \mathrm{mg} \mathrm{Cd}$ per kg dry matter is reached, such hectares receive the status of being 'clean' (see

Figure 2, the green cells). On these hectares new crops resulting in much higher labor income per ha can be cultivated, e.g. vegetables for industrial processing. The yearly labor income per hectare after the remediation target has been reached is assumed to be $50 \%$ (with a range between $0 \%$ and $100 \%$ ) higher than currently $(€ 1.100)$.

\section{NET PRESENT VALUE OF LABOR INCOME OVER 40 YEARS}

\subsection{Scenario building}

In switching the current land use (roughage) towards metal accumulator crops, the labor income per hectare would change. We distinguish three scenarios according to the number of ha (on a total of 36) allocated in the starting year to the crops rape, willow and roughage.

The first scenario describes a social acceptable, but weak phytoremediation activity. The cultivation scheme for a 'modal' farmer starts with 14 ha of rape (in 4 year rotation), 4 ha of willow (with harvest every $4^{\text {th }}$ year) and 18 ha of roughage. In the second scenario rape and willow are allocated 9 ha each. In the third scenario - at the moment not in favor of the farmers - willow is cultivated on 14 ha, leaving only 4 ha for rape.

Common to all scenarios, the assumed values for important parameters are surrounded with uncertainty. To deal with this, we introduce ranges for such estimates, characterized with a minimal, a most likely and a maximal value (see Table 4, columns 1a, 1b, 1c). The assumed probability distribution for the values within such intervals is mostly triangular of a symmetrical (the likeliest value lies in the middle) or asymmetrical (the likeliest value lies either to the left or to the right of the middle) form (see Table 4, column 2).

\subsection{Scenario results on NPV and 'cleaned' area}

For every scenario the NPV over 40 years is predicted using the Monte-Carlo simulation technique (10.000 runs). Such a simulation results in a probability distribution for the predicted NPV, characterized with the usual statistical measures. We look at the median value for the NPV (see Table 4, column 3). We also look at the probability that the NPV resulting from a scenario would be lower than the benchmark, the NPV of the current land use, roughage used for dairy cattle rearing (see Table 4, column 4). 


\begin{tabular}{|c|c|c|c|c|c|c|c|c|}
\hline & (1a) & (1b) & (lc) & (2) & (3) & (4) & (5) \\
\hline & & \multirow[b]{2}{*}{ Min } & \multirow[b]{2}{*}{$\begin{array}{l}\text { Like- } \\
\text { liest }\end{array}$} & \multirow[b]{2}{*}{ Max } & \multirow[b]{2}{*}{$\begin{array}{c}\text { Assumed } \\
\text { distri- } \\
\text { bution }\left({ }^{\circ}\right)\end{array}$} & \multicolumn{2}{|c|}{$\begin{array}{c}\text { Net Present } \\
\text { Value }(40 \mathrm{yrs})\end{array}$} & \multirow[b]{2}{*}{$\begin{array}{c}\text { Area } \\
\text { 'cleaned' } \\
(\%) \text { in } \\
\text { year } 40\end{array}$} \\
\hline & & & & & & $\begin{array}{l}\text { Median } \\
\text { (€) }\end{array}$ & $\begin{array}{l}\text { Probab. } \\
\text { (NPV } \\
\text { remed. } \\
< \\
\text { actual } \\
\text { NPV) }\end{array}$ & \\
\hline (1) & Price diesel $(€ /$ lit $)$ & 0.75 & 0.85 & 1 & tria sym & & & \\
\hline (2) & $\begin{array}{c}\text { Yearly growth price } \\
\text { diesel ( } \% / \text { year })\end{array}$ & 1 & 2 & 4 & tria asym & & & \\
\hline \multirow[t]{2}{*}{ (3) } & $\begin{array}{l}\text { Increase labor income } \\
\text { after remediationd } \% \text { ) }\end{array}$ & 0 & 50 & 100 & tria sym & & & \\
\hline & \multicolumn{8}{|c|}{ Scenario 1} \\
\hline (4a) & ha roughage & 18 & 18 & 18 & rect sym & \multirow{3}{*}{675,722} & \multirow{3}{*}{$62 \%$} & \multirow{3}{*}{$22 \%$} \\
\hline$(4 b)$ & ha rape & 4 & 14 & 16 & tria asym & & & \\
\hline \multirow[t]{2}{*}{$(4 c)$} & ha SRC (willow) & 2 & 4 & 6 & tria sym & & & \\
\hline & \multicolumn{8}{|c|}{ Scenario 2} \\
\hline (5a) & ha roughage & 18 & 18 & 18 & rect sym & \multirow{3}{*}{688,803} & \multirow{3}{*}{$33 \%$} & \multirow{3}{*}{$86 \%$} \\
\hline$(5 b)$ & ha rape & 3 & 9 & 12 & tria asym & & & \\
\hline \multirow[t]{2}{*}{$(5 c)$} & ha SRC (willow) & 3 & 9 & 12 & tria asym & & & \\
\hline & \multicolumn{8}{|c|}{ Scenario 3} \\
\hline (6a) & ha roughage & 18 & 18 & 18 & rect sym & \multirow{3}{*}{715,926} & \multirow{3}{*}{$15 \%$} & \multirow{3}{*}{$100 \%$} \\
\hline (6b) & ha rape & 2 & 4 & 6 & tria sym & & & \\
\hline$(6 c)$ & ha SRC (willow) & 4 & 14 & 16 & tria asym & & & \\
\hline & tria $=$ triangular; re & cta & lar; & $1=s$ & metrical; & sym $=$ & symme & \\
\hline
\end{tabular}

\section{DISCUSSION}

Our research question was: 'what effects does the introduction of phytoremediation crops have on the NPV of the farmer's labor income per ha over a period like 40 years?' Our discussion considers the microeconomic case of a modal farmer with on average 36 ha. At first sight, allocating a relatively large surface to the crop with the highest uptake performance (willow) is not financially attractive: based on the ad hoc data, the yearly labor income per ha is negative for willow ( $€-98)$, while on the other hand rape, with a lower phytoremediating performance, gives an income of approximately $€ 390$ per ha.

Our results show although, that a cautious introduction of phytoremediation - in scenario 1 willow initially occupies only 4 of the total of 36 ha, while the cash crop rape is assigned 14 ha - is not the optimal strategy. The NPV over 40 years of the farmer's labor income, with a median value of $€ 675,722$ (see Table 4, row 4, column 3 ) is slightly lower than the NPV of the current activity, $€ 679,500$, the benchmark. Moreover, taking into account the uncertainty surrounding the assumed values for five important parameters, the probability that the NPV of 
scenario 1 is lower than the reference of $€ 679,500$ is high: $62 \%$ (see Table 4 , row 4 , column 4). Only $22 \%$ of the surface reached the remedial target level of $1.8 \mathrm{~kg} \mathrm{Cd} / \mathrm{ha}$ (corresponding to $0.5 \mathrm{mg} / \mathrm{kg} \mathrm{d.m}$ ).

In scenario 2 at the start willow and rape each occupy 9 ha out ofe 36 . The median value of the NPV, $€ 688,803$ (see Table 4, row 5, column 3) is now $1.6 \%$ higher than the benchmark, and the probability that the NPV of phytoremediation is lower than currently is halved to $32 \%$ (see Table 4, row 5, column 4). It is remarkable that already $86 \%$ of the surface is 'cleaned'.

This evolution is confirmed in scenario 3 where we start with 14 ha of willow and only 4 ha of rape. This results in the sanitation of the total 36 ha after 32 years (willow has a higher uptake performance than rape). The median value of the NPV now is $€ 715,926$ (see Table 4, row 6 , column 3 ) i.e. $5.4 \%$ higher than the benchmark due to the expected higher labor income on a 'cleaned' ha. In this scenario the probability of obtaining a lower value for the NPV than currently is only $15 \%$.

Scenarios 1 to 3 describe a lager role for willow as the accumulating crop. The resulting increase in the NPV mainly can be explained by the larger number of ha reaching the reclamation target so that the farmer can profit from the expected increase in the labor income from higher value crops (which were prohibited on the polluted soil) on this 'clean' surface.

This leads us to the question: which future increase in labor income per ha on a 'clean' soil is necessary so that the median value of the NPV of the phytoremediation activity is at least as high as the benchmark (the NPV of the labor income earned through roughage for cattle), while at the same time the probability of a lower NPV outcome is equal or less than $5 \%$ ? We can calculate this future increase in labor income per ha for the 3 scenarios. The results are presented in Table 5.

Table 5 Necessary growth in labor income on clean soil

\begin{tabular}{|c|c|c|c|c|c|c|c|c|c|c|}
\hline & & (la) & (1b) & (1c) & (2) & (3) & (4) & (5) & (7) & (8) \\
\hline & Scen & & hectar & & Grow & labor ince & me on $\mathrm{c}$ & lean soil & & Probabi- \\
\hline & ario & $\begin{array}{l}\text { roug- } \\
\text { hage }\end{array}$ & rape & willow & Min & Likeliest & Max & Distrib $^{3}$ & (Median) & $\begin{array}{c}(\mathrm{NPV}< \\
\text { actual })\end{array}$ \\
\hline (1) & 1 & 18 & 14 & 4 & $90 \%$ & $90 \%$ & $180 \%$ & $\triangle$ & 703,212 & $5 \%$ \\
\hline (2) & 2 & 18 & 9 & 9 & $55 \%$ & $55 \%$ & $110 \%$ & $\triangle$ & 709,452 & $5 \%$ \\
\hline (3) & 3 & 18 & 4 & 14 & $40 \%$ & $40 \%$ & $80 \%$ & $\triangle$ & 727,262 & $4 \%$ \\
\hline
\end{tabular}

Source: personal calculations

The more ha of willow that is started with, the lower the expected growth in labor income on future clean soil has to be to realize (with $95 \%$ probability) a NPV that is not lower than today (see Table 5 column $1 \mathrm{c}$ and 3 ). When initially there are only 4 ha of willow, the future labor income on cleaned hectares should be at least $90 \%$ higher than today, to reach a $95 \%$ probability that the NPV will not be lower than the NPV of the current activity. On the

\footnotetext{
${ }^{3}$ The right-angled triangle symbol expresses the assumption that the minimal and likeliest value have the same probability (see left hand side of the triangle), while the probabilities of larger values (until the maximum) decrease to zero (see right hand side of the triangle).
} 
contrary, when it is started with 14 ha of willow, this future increase in labor income on cleaned soil should only be at least $40 \%$.

\section{CONCLUSION}

This paper investigates the viability of a phytoremediation activity embedded in a 'land management' approach. The question is: 'what effects does the introduction of phytoremediation crops have on the net present value (NPV) of the farmer's labor income per ha over a period like 40 years?' The discussion considers the microeconomic case of a modal farmer with on average 36 ha. The research methodology duly takes into account the uncertainty of the assumed values for important parameters. For every scenario the NPV is predicted using the Monte-Carlo simulation technique.

At first sight, allocating a relatively large surface to the crop with the highest uptake performance (willow) is not financially attractive because it is associated with a negative yearly labor income per ha. Rape, on the other hand rape, with a lower phytoremediating performance, can be considered as the 'cash crop': it gives a yearly income of approximately $€ 390$ per ha.

The results for the case study of 'the Kempen' show although, that a cautious introduction of phytoremediation - willow initially occupies only 4 ha, while the cash crop rape is assigned $14 \mathrm{ha}$ - is not the optimal strategy. A more 'innovating' approach, with an initial relatively intensive use of willow compared to rape, results in a faster remediation and because a 'cleaned' ha offers a higher labor income, this explains the higher outcomes for the NPV.

If such is the case, government could provided an incentive to tide over the period of reclamation with its lower yearly income, e.g. in the form of income tax exemptions or subsidies to cultivate willow. Such support could be recovered from the higher incomes after the reclamation. On the other hand such support can be seen as remuneration for the positive external effects emanating from the faster reclamation of the polluted area.

\section{REFERENCES}

[1] Bishop, J., 1997. Phytoremediation: A New Technology Gets Ready to Bloom, Environmental Solutions, Vol. 10:4.

[2] Salt, D.E., M. Blaylock, P.B.A. Nanda Kumar, V. Dushenkov, B.D. Ensley, I. Chet, and I. Raskin. 1995. Phytoremediation: A novel strategy for the removal of toxic metals from the environment using plants. Biotechnology, Vol. 13, p.468-474.

[3] EPA, 2000. Introduction to phytoremediation, Environmental Protection Agency, Washington, U.S., $72 \mathrm{p}$.

[4] ITRC, 1999 Phytoremediation decision tree, Interstate Technology and Regulatory Work Group, USA, 25 p.

[5] Robinson B, Fernandez JE, Madejon P, Maranon T, Murillo JM, Green S, Clothier B, 2003. Phytoextraction: an assessment of biogeochemical and economic viability, Plant and Soil Vol. 249 1, p.117-125.

[6] Vassilev, A., Schwitzguébel, J-P, Thewys, T., van der Lelie, D., Vangronsveld, J., 2004. The use of plants for remediation of metal contaminated soils, TheScientificeVorldJOURNAL, Vol. 4, p.9-34.

[7] Belgian National Institute for Statistics, 2005. Agricultural survey. 